"Tests of quantitative investing strategies of famous investors: case of Thailand"

\begin{tabular}{|c|c|}
\hline AUTHORS & $\begin{array}{l}\text { Paiboon Sareewiwatthana } \\
\text { Patarapon Janin }\end{array}$ \\
\hline ARTICLE INFO & $\begin{array}{l}\text { Paiboon Sareewiwatthana and Patarapon Janin (2017). Tests of quantitative } \\
\text { investing strategies of famous investors: case of Thailand. Investment } \\
\text { Management and Financial Innovations, 14(3), 218-226. doi:10.21511/imfi.14(3- } \\
\text { 1).2017.06 }\end{array}$ \\
\hline DOI & http://dx.doi.org/10.21511/imfi.14(3-1).2017.06 \\
\hline RELEASED ON & Thursday, 09 November 2017 \\
\hline RECEIVED ON & Thursday, 13 July 2017 \\
\hline ACCEPTED ON & Wednesday, 13 September 2017 \\
\hline LICENSE & $\begin{array}{l}(c) \text { EY-NG } \\
\text { This work is licensed under a Creative Commons Attribution-NonCommercial } 4.0 \\
\text { International License }\end{array}$ \\
\hline JOURNAL & "Investment Management and Financial Innovations" \\
\hline ISSN PRINT & $1810-4967$ \\
\hline ISSN ONLINE & $1812-9358$ \\
\hline PUBLISHER & LLC "Consulting Publishing Company "Business Perspectives" \\
\hline FOUNDER & LLC "Consulting Publishing Company "Business Perspectives" \\
\hline
\end{tabular}

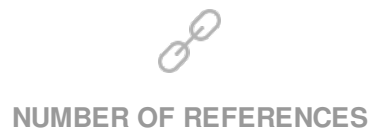

31
NUMBER OF FIGURES

1
$-=-$
$=-5$
$-=-$

NUMBER OF TABLES

4

(C) The author(s) 2023. This publication is an open access article. 


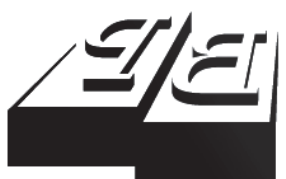

BUSINESS PERSPECTIVES

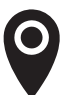

LLC "CPC "Business Perspectives" Hryhorii Skovoroda lane, 10, Sumy, 40022, Ukraine

www.businessperspectives.org

Received on: $13^{\text {th }}$ of July, 2017 Accepted on: $13^{\text {th }}$ of September, 2017

(c) Paiboon Sareewiwatthana, Patarapon Janin, 2017

Paiboon Sareewiwatthana, Ph.D., School of Business, National Institute of Development Administration, Bangkok, Thailand.

Patarapon Janin, Phillip Securities, Bangkok, Thailand.

\section{(ㄷ)(1) $(9$}

This is an Open Access article, distributed under the terms of the Creative Commons Attribution-NonCommercial 4.0 International license, which permits re-use, distribution, and reproduction, provided the materials aren't used for commercial purposes and the original work is properly cited.

\title{
TESTS OF QUANTITATIVE INVESTING STRATEGIES OF FAMOUS INVESTORS: CASE OF THAILAND
}

\begin{abstract}
This research studied quantitative investing strategies of famous investors in the Stock Exchange of Thailand from 2002 to 2016. This study found that the Graham's net nets, Dreman's contrarian, Fisher's super stock, O'Neil's CANSLIM, Slater's zulu principle, Neff's Cheapo, O'Shaughnessy's tiny titans, Greenblatt's magic formula, Carlisle's acquirer's multiple and Piotroski's F-score strategies beat the market (SET TRI). It also found that the Benjamin Graham's net nets strategy which used the market capitalization of less than two thirds of net current assets value (NCAV) criterion produced the highest return among the strategies used. However, the Tobias Carlisle's Acquirer's multiple strategy which used EBIT to enterprise value (EBIT/EV) to sort stocks for 30 stocks yielded the highest risk-adjusted return.
\end{abstract}

Keywords

\section{JEL Classification G11, G14}

\section{INTRODUCTION}

There has been a trend to study famous investors' strategies that have been proven to beat the market in the long term. Certain investors have been renowned internationally, for example, Benjamin Graham who studied the strength of financial statements in finding the true value of companies. Others include David Dreman who used behavioral finance on overreaction, Kenneth Fisher who invested in companies during the down product life cycle, Jim Slater who used the price to earnings to growth strategy (PEG) coupled with other indicators, Joel Greenblatt who employed earnings yield and return on capital, Tobias Carlisle who used EBIT/EV, and Joseph Piotroski who used 9 financial statement factors.

From the success of the above investors, there have been various researches that tried to measure the effectiveness of these strategies in developed markets like the United States and Japan. However, this kind of quantitative study is still not popular in Thailand, which leads to this paper. The focus is to study if the strategies mentioned are suitable to the Stock Exchange of Thailand.

This research is divided into 3 sections. The opening section is the introduction. The first section is the review of past literature related to famous investors' investment strategies. The second section is the data and research methodology. The third section is the presentation of results, and the final is the conclusion and recommendations for future studies. 


\section{LITERATURE REVIEW}

Past researches studied investment strategies of famous internationally acclaimed investors, applied to developed markets. These strategies are as follows.

$1^{\text {st }}$ strategy: Graham (1949) used a market capitalization lower than $2 / 3$ of its net current assets. Testing by Oppenheimer (1986) in the New York Stock Exchange, Bildersee et al. (1993) in the Tokyo Stock Exchange, and Xiao and Arnold (2008) in the FTSE found that the strategy beats the market. However, Dudzinski and Kunkel (2014) found that only small number of stocks could pass the criteria.

$2^{\text {nd }}$ strategy: Dreman and Lufkin (1997) employed the $\mathrm{P} / \mathrm{E}$ ratio, $\mathrm{P} / \mathrm{B}$ ratio, and price to cash flow in the lowest $20 \%$ of the market. In addition, Lehmann (1990) and Lo and MacKinlay (1990) found that under this strategy, the price of a stock could revert in a short period of time, for example, a week's loss could be reversed in the following week.

$3^{\text {rd }}$ strategy: Fisher (1984) used a price to sales ratio lower than 0.75 times, a net profit margin higher than $5 \%$, and debt to equity ratio lower than 0.4 times, while Barbee et al. (1996) found that the $\mathrm{D} / \mathrm{E}$ to sales has a statistically significant positive correlation with investment returns.

$4^{\text {th }}$ strategy: O'Neil (2009) introduced CANSLIM which is based on fundamental stock analysis. From the studies by Lutey et al. (2013), Olson et al. (1998) and Cheh et al. (2012) in the S\&P 500, and Najafi and Asgari (2013) in the Stock Exchange of Tehran, it was found that CANSLIM yielded higher returns than the markets. However, Gillette (2005) tested the strategy in the Germany DAX index and found that the risk adjusted returns were lower than the market.

$5^{\text {th }}$ and $6^{\text {th }}$ strategies: Slater (2010) and Neff (2001) both worked with PEG, P/E, NI, EPS, and dividend yield. Peters (1991) tested the PEG in the S\&P 500 and Chahin and Choudhry (2010) tested the PEG in the Euro zone, and both found that portfolios consisting of low PEG gave higher returns than portfolios with higher PEG ratios. $7^{\text {th }}$ strategy: O'Shaughnessy (2006) picked stocks with a low market capitalization, price to sales ratio lower than 1 , and a price relative strength. Brooks et al. (2001) tested the strategy in the FTSE and found that it gave a higher Sharpe ratio than the market, indicating that the strategy outperformed the FTSE index.

$8^{\text {th }}$ strategy: Greenblatt (2006) analyzed earnings yield and return on capital. Tests by Larkin (2009) in the S\&P500 from 1998 to 2006 found that the returns outperformed the market and gave a positive return every year. However, this portfolio did not yield the best return, since a portfolio that used the book-to-market ratio and firm size gave a higher return.

$9^{\text {th }}$ strategy: Carlisle (2014) examined EBIT to enterprise value. DrKW Macro Research (2006) compared two strategies, the first using EBIT to enterprise value and ROI, and the second using purely EBIT to enterprise value. The study found that the former strategy gave a higher return in the Japanese market, while the latter gave a higher return in the European, United Kingdom, and the United States markets.

$10^{\text {th }}$ strategy: Piotroski (2000) introduced the $9^{\text {th }}$ criterion called the F-score. Abarbanell and Bushee (1997, 1998) and Mohanram (2005) tested the strategy in the United States and found that portfolios with a higher F-score gave a statistically significant higher return than a portfolio with a lower F-score.

\section{DATA AND RESEARCH METHODOLOGY}

This research studied the effectiveness of quantitative investing strategies of famous investors, applied to the Stock Exchange on Thailand from 2002 to 2016 for a period of 14 years. The data are collected from Thomson Reuters Datastream. With equal weight, annual returns were measured for the period from the $15^{\text {th }}$ of March to the $14^{\text {th }}$ of March of the following year. This was to match with listed companies' annual financial statements published through the Stock Exchange of Thailand every February. 


\subsection{Portfolio construction of each investment strategy}

1. Benjamin Graham's net nets portfolio

- Calculate the net current assets from total current assets subtracted by total liabilities.

- Divide the market capitalization by the net current assets value.

- Invest in stocks that yield $2 / 3$ or less of the above ratio, as illustrated in equation (1), by allocating equal amounts of money in each stock.

$$
\frac{\text { Market capitalization }}{\text { Net current assets value }} \leq \frac{2}{3}
$$

\section{David Dreman's contrarian portfolio}

- Rank stocks by the lowest P/E (price to earnings), the lowest is assigned a score of 1 .

- Rank stocks by the lowest P/B (price to book), the lowest is assigned a score of 1 .

- Rank stocks by the lowest P/CF (price to cash flow), the lowest is assigned a score of 1 .

- Add the scores of the stocks from the 3 criteria above.

- $\quad$ Select three stocks with the lowest score from 8 industries, for a total of 24 stocks, investing an equal amount of money in each stock.

3. Kenneth Fisher's super stock portfolio

- Select stocks with a price to sales ratio lower than 0.75 .

- Select stocks with a net profit margin higher than $5 \%$.

- Select stocks with a debt to equity ratio lower than 0.4 .

- Invest in stocks that passed the three criteria, allocating equal amounts of money in each stock.
4. William J. O’Neil's CANSLIM portfolio

- Select stocks with a quarterly year on year EPS growth of higher than $20 \%$.

- Select stocks with a compounded 3 year EPS growth rate of more than $25 \%$.

- Select stocks with a return on equity (ROE) higher than $17 \%$.

- Invest in stocks that passed all three criteria, allocating equal amounts of money in each stock.

5. Jim Slater's zulu principle portfolio

- Select stocks with a PEG ratio lower than 0.75 .

- Select stocks with a $\mathrm{P} / \mathrm{E}$ ratio lower than $20 \mathrm{x}$.

- Select stocks with a positive net income in the previous 4 years, with the current year being the highest.

- Select stocks which have an increasing EPS ratio in the previous 4 years, with the current year being the highest.

- Invest in stocks that passed all criteria, allocating equal amounts of money in each stock.

6. John Neff's Cheapo portfolio

- Add a stocks' compounded 5 year EPS growth rate with its dividend yield to get the stock's total return.

- Divide the total return with the stock's P/E to get the total return ratio.

- Divide sum of all the total return ratio in the market by the number of stocks in the market to get the market average total return ratio.

- Invest in stocks with a total return ratio higher than two times the market average total return, allocating equal amounts of money in each stock. 
7. James P. O'Shaughnessy's tiny titans portfolio

- Calculate a stock's rate of change in stock price from the previous year's price.

- Calculate the rate of change in the SET index, compared to the previous year's index.

- Divide the rate of change in stock price by the rate of change in SET index to find the relative strength, with the highest assigned a score of 1 .

- Select stocks with a price-to-sales ratio lower than 1.

- Select stocks with a market capitalization lower than 20 billion baht.

- Invest in the lowest 25 scoring stocks, allocating equal amounts of money in each stock.

8. Joel Greenblatt's magic formula portfolio

- Divide the EBIT by the enterprise value to find the earnings yield.

- Subtract total assets by current liabilities to find the net current assets.

- Select stocks with a positive net current assets.

- Divide the EBIT by the net current assets to find the return on capital.

- Rank stocks by the highest earnings yield, with the highest assigned a score of 1 .

- Rank stocks by the highest return on capital, with the highest assigned a score of 1 .

- Add the scores of the stocks from the 2 criteria above.

- Invest in the lowest 30 scoring stocks, allocating equal amounts of money in each stock.

9. Tobias Carlisle's acquirer's multiple portfolio
- Divide the EBIT by it the enterprise value to find the enterprise multiple.

- Rank stocks by its enterprise multiple, with the highest assigned a score of 1 .

- Invest in the lowest 30 scoring stocks, allocating equal amounts of money in each stock.

10. Joseph Piotroski’s F-score portfolio

- Select stocks with a positive net income in the current year, assign a score of 1 .

- Select stocks with a positive operating cash flow in the current year, assign a score of 1 .

- $\quad$ Select stocks with a return on assets (ROA) in the current year higher than the return on assets of the previous year, assign a score of 1 .

- Select stocks with a higher operating cash flow than net income, assign a score of 1 .

- Select stocks with a long term debt of the current year lower than the long term debt of the previous year, assign a score of 1 .

- Select stocks with a current ratio higher than the current ratio of the previous year, assign a score of 1 .

- Select stocks with the number of common shares outstanding in the current year lower than or equal to the number of shares outstanding in the previous year, assign a score of 1 .

- Select stocks that have a gross profit margin higher than the previous year's gross profit margin, assign a score of 1 .

- Select stocks that have an asset turnover ratio higher than the asset turnover ratio of the previous year, assign a score of 1 .

- Combine the scores from criteria 1-9.

- Invest in stocks that have a score of 8-9, allocating an equal amounts of money in each stock. 


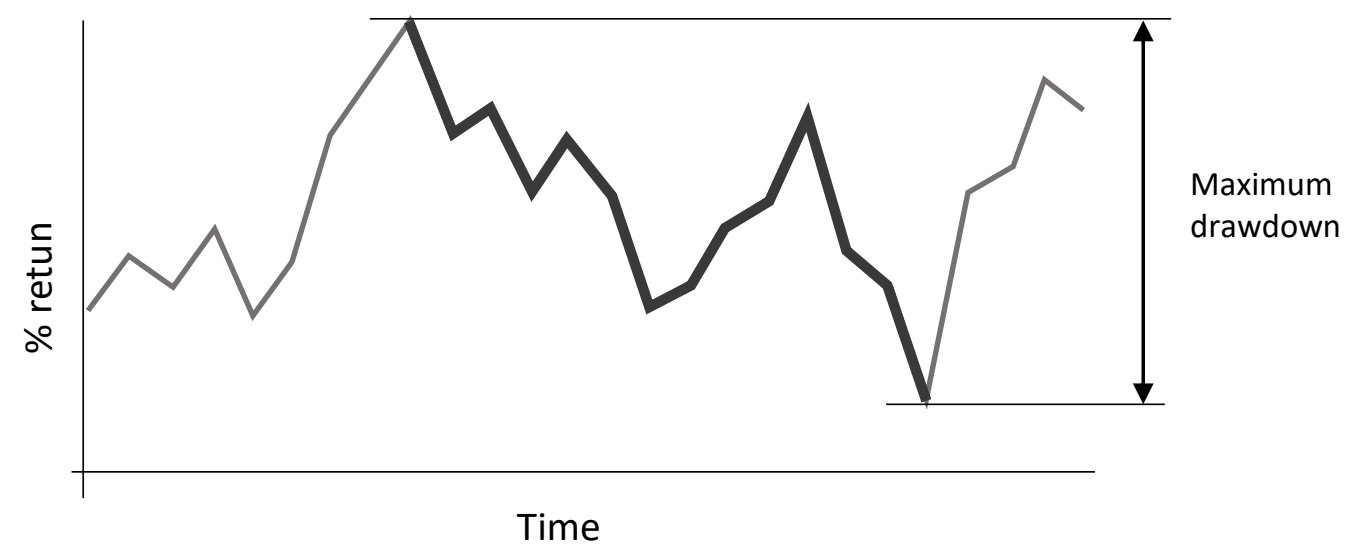

Figure 1. Maximum drawdown

\subsection{Testing the effectiveness of each investment strategy}

1. Compare the annual returns with the return from the Stock Exchange of Thailand (SET TRI) using the total return, geometric mean return and the number of stocks.

2. Compare the Sharpe ratio of each portfolio in a given year with the total return from the Stock Exchange of Thailand (SET TRI). The Sharpe ratio measures the portfolio risk adjusted returns. It is calculated by the portfolio return less the returns on 1 year government bonds, divided by the standard deviation of the portfolio return.

$$
\text { Sharpe ratio }=\frac{\left(\begin{array}{c}
\text { Portfolio } \\
\text { return }
\end{array}\right)-\left(\begin{array}{c}
\text { Risk } \\
\text { free rate }
\end{array}\right)}{\begin{array}{l}
\text { Standard deviation } \\
\text { of portfolio return }
\end{array}} .
$$

3. Compare the Sharpe ratio, annual return, standard deviation and the maximum drawdown over the course of 14 years of investment of each of the 10 portfolios. The maximum drawdown shows the maximum percentage loss in any given time during the investment period, calculated from the highest point to the lowest point in the graph, as illustrated by Figure 1.

Table 1. Returns from each portfolio in each year, compared to the returns from the SET TRI

\begin{tabular}{|c|c|c|c|c|c|c|c|c|c|c|c|}
\hline Year & SET TRI & Graham & Dreman & Fisher & O'Neil & Slater & Neff & O'Shaugh & Greenblatt & t Carlisle & Piotroski \\
\hline 2002 & $-1.80 \%$ & $-1.78 \%$ & $5.04 \%$ & $12.08 \%$ & $13.71 \%$ & $0.00 \%$ & $5.88 \%$ & $16.84 \%$ & $37.50 \%$ & $25.40 \%$ & $25.09 \%$ \\
\hline 2003 & $96.45 \%$ & $141.74 \%$ & $112.50 \%$ & $73.14 \%$ & $76.75 \%$ & $98.08 \%$ & $67.41 \%$ & $108.93 \%$ & $64.41 \%$ & $80.49 \%$ & $108.27 \%$ \\
\hline 2004 & $6.58 \%$ & $40.67 \%$ & $1.76 \%$ & $5.13 \%$ & $-2.00 \%$ & $24.66 \%$ & $5.87 \%$ & $-6.82 \%$ & $-0.41 \%$ & $-3.82 \%$ & $7.34 \%$ \\
\hline 2005 & $11.10 \%$ & $108.51 \%$ & $-0.60 \%$ & $12.86 \%$ & $7.75 \%$ & $0.00 \%$ & $11.07 \%$ & $-0.94 \%$ & $4.14 \%$ & $21.73 \%$ & $15.76 \%$ \\
\hline 2006 & $-5.32 \%$ & $-22.10 \%$ & $-3.01 \%$ & $9.75 \%$ & $29.01 \%$ & $33.42 \%$ & $-1.78 \%$ & $7.24 \%$ & $34.59 \%$ & $30.02 \%$ & $6.53 \%$ \\
\hline 2007 & $26.33 \%$ & $12.24 \%$ & $8.87 \%$ & $15.24 \%$ & $19.45 \%$ & $27.18 \%$ & $15.69 \%$ & $21.41 \%$ & $18.03 \%$ & $17.74 \%$ & $15.86 \%$ \\
\hline 2008 & $-45.23 \%$ & $-0.66 \%$ & $-17.08 \%$ & $-23.66 \%$ & $-26.44 \%$ & $-49.79 \%$ & $-31.59 \%$ & $-33.65 \%$ & $-29.80 \%$ & $-19.19 \%$ & $-23.99 \%$ \\
\hline 2009 & $80.89 \%$ & $124.15 \%$ & $99.40 \%$ & $105.45 \%$ & $79.22 \%$ & $185.35 \%$ & $88.81 \%$ & $75.56 \%$ & $111.43 \%$ & $117.22 \%$ & $79.99 \%$ \\
\hline 2010 & $43.43 \%$ & $64.69 \%$ & $47.37 \%$ & $64.44 \%$ & $63.89 \%$ & $0.00 \%$ & $54.29 \%$ & $93.65 \%$ & $65.73 \%$ & $59.04 \%$ & $53.26 \%$ \\
\hline 2011 & $22.00 \%$ & $7.73 \%$ & $18.60 \%$ & $11.77 \%$ & $22.38 \%$ & $43.59 \%$ & $24.08 \%$ & $21.46 \%$ & $28.16 \%$ & $29.41 \%$ & $25.41 \%$ \\
\hline 2012 & $41.08 \%$ & $59.27 \%$ & $85.58 \%$ & $108.15 \%$ & $44.31 \%$ & $73.12 \%$ & $64.60 \%$ & $91.86 \%$ & $84.24 \%$ & $70.50 \%$ & $81.13 \%$ \\
\hline 2013 & $-11.27 \%$ & $32.76 \%$ & $-3.12 \%$ & $-25.04 \%$ & $-15.18 \%$ & $-3.88 \%$ & $1.38 \%$ & $-15.62 \%$ & $-16.21 \%$ & $-8.90 \%$ & $-12.29 \%$ \\
\hline 2014 & $15.91 \%$ & $192.06 \%$ & $60.77 \%$ & $81.72 \%$ & $38.91 \%$ & $33.35 \%$ & $46.39 \%$ & $47.81 \%$ & $47.45 \%$ & $42.58 \%$ & $45.33 \%$ \\
\hline 2015 & $-7.32 \%$ & $-39.72 \%$ & $-13.56 \%$ & $-3.51 \%$ & $-16.83 \%$ & $-7.37 \%$ & $-7.55 \%$ & $-25.64 \%$ & $-11.86 \%$ & $-5.35 \%$ & $-7.65 \%$ \\
\hline $\begin{array}{c}\text { Total } \\
\text { return }\end{array}$ & $536.95 \%$ & $8853.58 \%$ & $1621.26 \%$ & $2196.96 \%$ & $1122.85 \%$ & $1671.96 \%$ & $1222.71 \%$ & $1330.11 \%$ & $2255.59 \%$ & $2972.48 \%$ & $2139.84 \%$ \\
\hline GeoMean & $14.14 \%$ & $37.86 \%$ & $22.54 \%$ & $25.09 \%$ & $19.58 \%$ & $22.79 \%$ & $20.26 \%$ & $20.93 \%$ & $25.32 \%$ & $27.72 \%$ & $24.87 \%$ \\
\hline
\end{tabular}


Table 2. Number of stock holdings in each portfolio

\begin{tabular}{|c|c|c|c|c|c|c|c|c|c|c|}
\hline Year & Graham & Dreman & Fisher & $\mathbf{O}^{\prime}$ Neil & Slater & Neff & O'Shaugh & Greenblatt & Carlisle & Piotroski \\
\hline 2002 & 6 & 24 & 20 & 2 & 0 & 25 & 25 & 30 & 30 & 59 \\
\hline 2003 & 6 & 24 & 20 & 15 & 1 & 32 & 25 & 30 & 30 & 48 \\
\hline 2004 & 1 & 24 & 14 & 26 & 2 & 33 & 25 & $31^{a}$ & 30 & 39 \\
\hline 2005 & 3 & 24 & 21 & 27 & 0 & 31 & 25 & 30 & 30 & 44 \\
\hline 2006 & 7 & 24 & 25 & 24 & 1 & 41 & 25 & 30 & 30 & 28 \\
\hline 2007 & 8 & 24 & 24 & 27 & 1 & 42 & 25 & 30 & 30 & 60 \\
\hline 2008 & 11 & 24 & 26 & 19 & 6 & 71 & 25 & 30 & 30 & 39 \\
\hline 2009 & 29 & 24 & 30 & 23 & 1 & 54 & 25 & 30 & 30 & 62 \\
\hline 2010 & 9 & 24 & 31 & 26 & 0 & 59 & 25 & 30 & 30 & 55 \\
\hline 2011 & 5 & 24 & 27 & 41 & 3 & 28 & 25 & 30 & 30 & 60 \\
\hline 2012 & 5 & 24 & 23 & 32 & 3 & 25 & 25 & 30 & 30 & 43 \\
\hline 2013 & 3 & 24 & 11 & 61 & 15 & 15 & 25 & 30 & 30 & 57 \\
\hline 2014 & 4 & 24 & 12 & 31 & 11 & 30 & 25 & 30 & 30 & 41 \\
\hline 2015 & 1 & 24 & 12 & 24 & 10 & 69 & 25 & 30 & 30 & 35 \\
\hline
\end{tabular}

Note: a two stocks were ranked equally, therefore making the total holdings 31 stocks.

Rank the portfolios by their Sharpe ratios, with the highest ratio ranked first, to find the portfolio that yielded the highest risk adjusted return in each of the 14 years of investment (15 March 2002 to 14 March 2016).

\section{FINDINGS}

1. As seen in Table 1, when comparing the returns from each portfolio with the total return from the Stock Exchange of Thailand (SET TRI), the study found that all 10 portfolios yielded higher returns than the market. The portfolio that gave the highest return over the period tested was Benjamin Graham's net nets, yielding $37.86 \%$ return per annum. However, the number of stock holdings in this portfolio was relatively fewer than other portfolios, making it less diversified. The portfolio that beat the market for the longest investment period was Tobias Carlisle's acquirer's multiple portfolio with better returns in 11 years out of 14 years of investment.

When comparing the returns from all portfolios throughout the 14 years of investment, Tobias Carlisle's acquirer's multiple portfolio gave the highest Sharpe ratio of 1.6184 . The portfolio risk adjusted return was $27.72 \%$ per annum, beating

Table 3. The Sharpe ratio of each portfolio and of the Stock Exchange of Thailand

\begin{tabular}{|c|c|c|c|c|c|c|c|c|c|c|c|}
\hline Year & SET TRI & Graham & Dreman & Fisher & $\mathbf{O}^{\prime}$ Neil & Slater & Neff & O'Shaugh & Greenblatt & Carlisle & Piotroski \\
\hline 2002 & 1477 & & 0.2044 & 0.8055 & 0.7038 & -139.4890 & 0.3043 & 0.6248 & 2.4910 & 2.2023 & 1.4773 \\
\hline 2003 & & & & & & & & & & & \\
\hline 2004 & & & & & & & & & & & \\
\hline 2005 & 0.5783 & 0.9251 & -0.0866 & 0.8257 & 0.4994 & -3.5211 & 0.8477 & -0.1558 & 0.1029 & 1.2157 & 1.3611 \\
\hline 2006 & -0.2020 & -1.0329 & -0.2750 & 0.4320 & 1.1690 & 0.7741 & -0.2475 & 0.3646 & 1.6907 & 1.6784 & 0.3046 \\
\hline 2007 & 1.1134 & 6528 & 0.5746 & 0.9858 & 1.2963 & 1.0231 & 1.0343 & 1.4768 & 0.9785 & 1.1565 & 1.4375 \\
\hline 2008 & -1.6476 & -0.0487 & -0.8030 & -1.0835 & -1.2621 & -1.9050 & -1.8344 & -0.7796 & -1.8525 & -1.1098 & -1.4470 \\
\hline 2009 & 7652 & .5518 & 4.4912 & 4.9164 & 4.1893 & 2.81 & 4.3407 & & 0 & & 984 \\
\hline 2010 & 1.9396 & 3852 & 2.6557 & 3.8933 & 3.1682 & -0.5080 & 3.1749 & 2.4565 & 3.6135 & 3.5823 & 3.3733 \\
\hline 2011 & 0.8345 & 0.3584 & 0.7422 & 0.6009 & 0.9338 & 1.6320 & 1.1106 & 0.9268 & 1.3777 & 1.6151 & 1.2811 \\
\hline 2012 & 2.1304 & 9154 & 4.9050 & 5.2884 & 2.9092 & 2.5978 & 4.2566 & 4.2691 & 5.4215 & 4.4901 & 5.9168 \\
\hline 2013 & -0.4815 & 0.8354 & -0.0495 & -0.8850 & -0.5810 & -0.2689 & 0.1911 & -0.6781 & -0.6456 & -0.3348 & -0.5963 \\
\hline 2014 & 1.2464 & 2.4630 & 3.7421 & 3.2319 & & 2.0860 & 2.7783 & 1.9276 & 2.4764 & 2.8666 & 2.9724 \\
\hline 2015 & -0.5267 & -0.6082 & -1.0165 & -0.2153 & -1.1011 & -0.4615 & -0.6395 & -1.2917 & -0.8086 & -0.6970 & -0.6839 \\
\hline
\end{tabular}


Table 4. Risk and return for all 10 portfolios over 14 years

\begin{tabular}{|c|c|c|c|c|}
\hline Strategy & $\begin{array}{c}\text { Sharpe } \\
\text { ratio }\end{array}$ & $\begin{array}{c}\text { Annual } \\
\text { return }\end{array}$ & $\begin{array}{l}\text { Standard } \\
\text { deviation }\end{array}$ & $\begin{array}{l}\text { Maximum } \\
\text { drawdown }\end{array}$ \\
\hline Carlisle's acquirer's multiple & 1.6184 & $27.72 \%$ & $14.11 \%$ & $-38.34 \%$ \\
\hline Piotroski's F-score & 1.4738 & $24.87 \%$ & $14.04 \%$ & $-36.97 \%$ \\
\hline Greenblatt's magic formula & 1.3968 & $25.32 \%$ & $15.14 \%$ & $-43.65 \%$ \\
\hline Fisher's super stock & 1.2647 & $25.09 \%$ & $16.83 \%$ & $-42.86 \%$ \\
\hline Neff's Cheapo & 1.1571 & $20.26 \%$ & $14.73 \%$ & $-44.02 \%$ \\
\hline Dreman's contrarian & 1.1157 & $22.54 \%$ & $17.27 \%$ & $-41.62 \%$ \\
\hline O'Neil's CANSLIM & 0.9932 & $19.58 \%$ & $17.32 \%$ & $-47.24 \%$ \\
\hline O'Shaughnessy's tiny titans & 0.8484 & $20.93 \%$ & $22.40 \%$ & $-59.82 \%$ \\
\hline Graham's net nets & 0.8280 & $37.86 \%$ & $44.92 \%$ & $-53.08 \%$ \\
\hline Slater's zulu principle & 0.8102 & $22.79 \%$ & $26.57 \%$ & $-59.72 \%$ \\
\hline SET TRI & 0.6385 & $14.14 \%$ & $20.36 \%$ & $-56.14 \%$ \\
\hline
\end{tabular}

the SET TRI of $14.14 \%$ per annum. It's maximum drawdown of $-38.34 \%$ was also the second smallest number, after Joseph Piotroski's portfolio.

2. When comparing the Sharpe ratio of all the portfolios in each year with the Stock Exchange of Thailand (SET TRI), this study found that the portfolio that yielded the high- est risk-adjusted return was different for each year. Benjamin Graham's net nets portfolio gave the highest return, but its Sharpe ratios were incongruent in several years, because the high returns were correlated with the high risk. Tobias Carlisle's acquirer's multiple tended to yield the highest risk adjusted returns, as illustrated in Table 3.

\section{CONCLUSION}

When applying the quantitative investing strategies of famous investors to the Stock Exchange of Thailand over the course of 14 years from 2002 to 2016, this study found that all strategies showed higher returns and higher Sharpe ratios than the market. Moreover, Benjamin Graham's net nets strategy of investing in stocks with a market capitalization lower than $2 / 3$ of net current asset value yielded the highest return. Tobias Carlisle's acquirer's multiple with 30 stocks of the highest EBIT to enterprise value, yielded the highest risk adjusted return.

However, this research is not without constraints. Stocks traded in the Stock Exchange of Thailand had low liquidity, which could affect trading in practice. We also did not seek to find the reason for each outperformance, for example, the size effect or the value effect. In addition, this research did not take into account the fees incurred from trading. Further constraints include the facts that the time period of 14 years may not be long enough and 2002-2016 is considered to be a bull period for the stock market. Therefore, this study encourages researchers to further study from these constraints.

\section{REFERENCES}

1. Abarbanell, J., \& Bushee, B. (1997) Fundamental analysis, future earnings, and stock prices. Journal of Accounting Research, 35(1), 1-24 https://doi.org/10.2307/2491464

2. Abarbanell, J., \& Bushee, B. (1998). Abnormal returns to a fundamental analysis strategy. The Accounting Review, 73(1), 19-45. Retrieved from http://www.jstor. org/stable/248340
3. Barbee, W., Mukherji, S., \& Raines, G. (1996). Do sales-price and debt-equity explain stock returns better than book-market and firm size? Financial Analysts Journal, 52(2), 56-60. Retrieved from http://www.jstor.org/stable/4479907

4. Bildersee, J. (1993). The performance of Japanese common stock in relation to their net current asset values. Japan and the World Economy, 5(3), 197-215. https://doi.org/10.1016/09221425(93)90011-R

5. Brooks, C., Chow, W., \& Ward, C. (2001). Can profitable trading strategies be derived from investment best-sellers? Journal of Asset Management, 2(2), 162-179. https://doi.org/10.1057/palgrave. jam. 2240042 
6. Carlisle, T. (2014). Deep value: Why activists investors and other contrarians battle for control of losing corporations. Wiley Finance.

7. Chahin, S. \& Choudhry, T. (2010). Price to earnings, growth ratio and value vs. growth based strategies: some European evidences. Social Science Research Network, 19(4). http://dx.doi.org/10.2139/ ssrn.498306

8. Cheh, J., Kim, I., \& Lee, J. (2012). Can a simplified version of CAN SLIM investment strategy produce abnormal returns for ordinary investors? Pan-Pacific Journal of Business Research, 3(1), 106-131. Retrieved from http://ppbri.org/ can-a-simplified-version-of-canslim-investment-strategy

9. Dreman, D., \& Lufkin, E. (1997) Do contrarian strategies work within industries? The Journal of Investing, 6(3), 7-29. https://doi. org/10.2469/dig.v28.n2.263

10. DrKW Macro Research (2006). Global equity strategy: the little note that beats the markets. Retrieved from http://www.poslovni. $\mathrm{hr} /$ media/forum-user-upload/files /9a/9a5c2b2f55b461120e8d01095 cf09a34.pdf

11. Dudzinski, J., \& Kunkel, R. (2014). Ben Graham's NCAV (net current asset value) technique in the $21 \mathrm{st}$ century. The Journal of Investing, 23(1), 17-26. https://doi. org/10.3905/joi.2014.23.1.017

12. Fisher, K. (1984). Super Stock (pp. 63-77). McGraw-Hill.

13. Gillette, L. (2005). An empirical test of German stock market efficiency. Center for Applied Statistics and Economics, Humboldt-Universitat zu Berlin, Germany. Retrieved from https://edoc.hu-berlin.de/handle/18452/14688

14. Graham, B. (1949). The intelligent investor. In J. Zweig (2006) (Ed.), The intelligent investor (revised edition). Harper Business

Essential.

15. Greenblatt, J. (2006). The little book that beats the market. Wiley.

16. Kumaran, S. (2013). Drawdown risk in mutual fund's performance. Journal of Finance and Investment Analysis, 2(2), 89-106. Retrieved from http://www.scienpress.com/Upload/JFIA/Vol\%20 2_2_6.pdf

17. Larkin, P. (2009). Can individual investors capture value premium? Journal of Business and Economic Research, 7(5), 25-33. Retrieved from https://www.cluteinstitute. com/ojs/index.php/JBER/article/ view/2287/2335

18. Lehmann, B. (1990). Fads, martingales, and market efficiency. The Quarter Journal of Economics, 105(1), 1-28. Retrieved from http://www.jstor.org/stable/2937816

19. Lo, A. \& MacKinlay, C. (1990). When are contrarian profits due to stock market overreaction? The Review of Financial Studies, 3(2), 175-205. Retrieved from http:// www.jstor.org/stable/2962020

20. Lutey, M., Crum, M., \& Rayome, D. (2013). Outperforming the broad market: an application of the CANSLIM strategy. ASBBS e-Journal, 9(1), 90-96. Retrieved from https://www.questia.com/ library/journal/1P3-3115873011/ outperforming-the-broad-marketan-application-of

21. Mohanram, P. (2005). Separating winners from losers among low book-to-market stocks using financial statement analysis. Review of Accounting Studies, 10(2-3), 133-170. https://doi.org/10.1007/ s11142-005-1526-4

22. Najafi, M., \& Asgari, F. (2013). Using CANSLIM analysis for evaluating stocks of the companies admitted in Tehran Stock Exchange. Journal of
American Science, 9(4s), 129-

134. Retrieved from http:// www.jofamericanscience.org/ journals/am-sci /am0904s/ 021_18102am0904s_129_134.pdf

23. Neff, J. (2001). John Neff on Investing. Wiley.

24. Olson, D., Nelson, J., Witt, C., \& Mossman, C. (1998). A test of the investor's daily stock ranking system. Financial Review, 33(2), 161-176. https://doi. org/10.1111/j.1540-6288.1998. tb01375.x

25. O'Neil, W. (2009). How to make money in stocks ( $4^{\text {th }}$ edition). New York: McGraw-Hill.

26. Oppenheimer, H. (1986). Ben Graham's net current asset values a performance update. Financial Analysts Journal, 42(6), 40-47. Retrieved from http://www.jstor. org/stable/4478980

27. O'Shaughnessy, J. (2006). Predicting the markets of tomorrow (pp. 163-166). New York: McGraw-Hill.

28. Peters, D. (1991). Valuing a growth stock. The Journal of Portfolio Management, 17(3), 49-51. https://doi.org/10.3905/ jpm.1991.409339

29. Piotroski, J. (2000). Value investing: the use of historical financial statement information to separate winners from losers. Journal of Accounting Research, 38(Supplement: studies on accounting information and the economics of the firm), 1-41. https://doi. org/10.2307/2672906

30. Slater, J. (2010). Beyond the zulu principle: extraordinary profits from growth shares. Harriman Modern Classics.

31. Xiao, Y., \& Arnold, G. (2008). Testing Benjamin Graham's net current asset value strategy in London. The Journal of Investing, 17(4), 11-19. http://dx.doi. org/10.2139/ssrn.966188 


\section{APPENDIX}

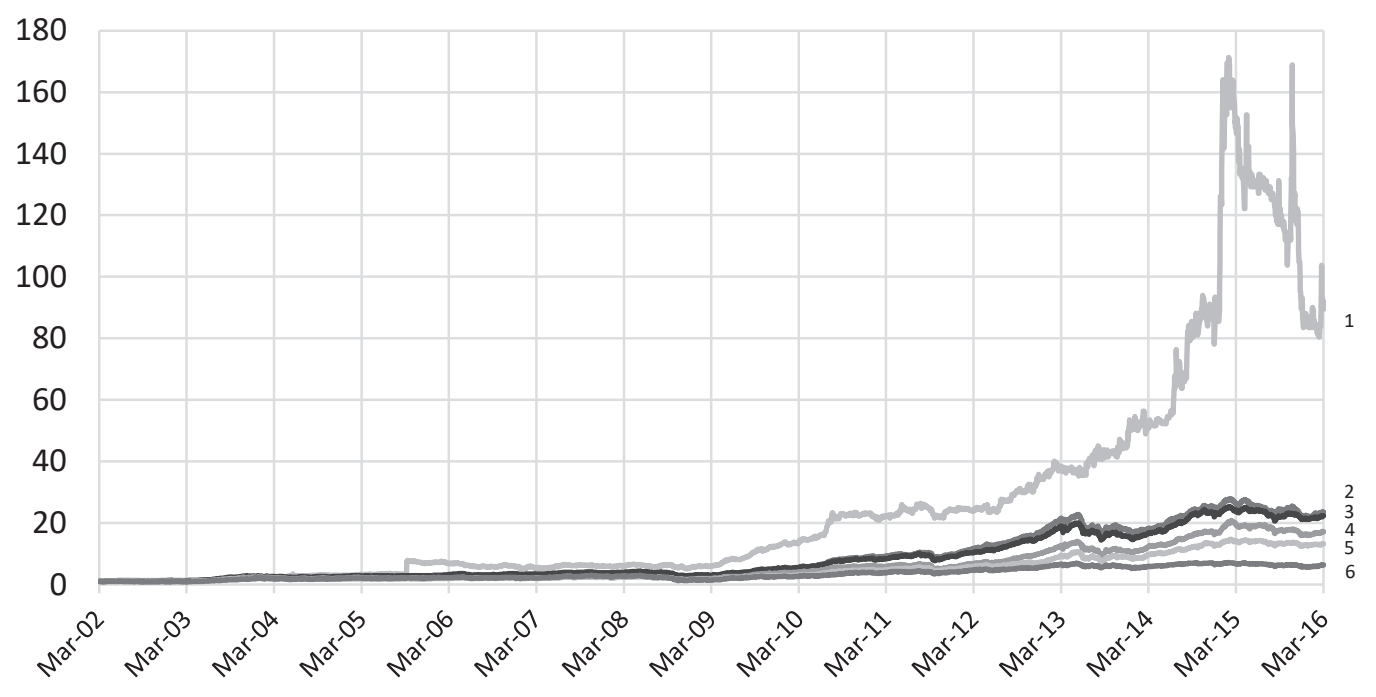

1. Graham's net nets

Figure A1. Accumulated value of each portfolio of the SET TRI over 14 years

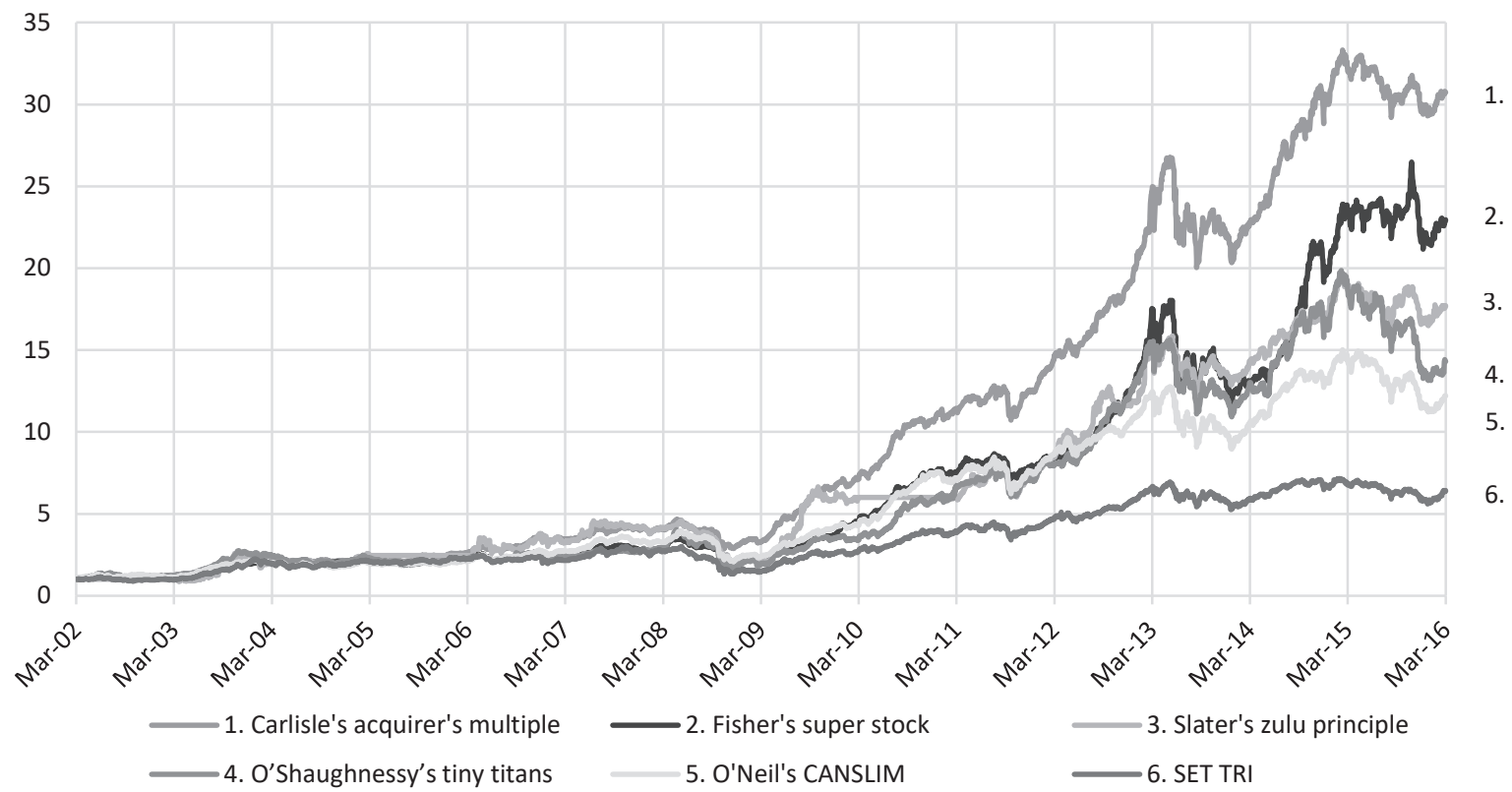

Figure A2. Accumulated value of each portfolio of the SET TRI over 14 years 